\title{
Comparative Studies of WC-Co and WC-Co-Ni Composites Obtained by Conventional Powder Metallurgy
}

Vinícius Martins ${ }^{\mathrm{a}}$, Wilson Corrêa Rodrigues ${ }^{\mathrm{a}}$, Peterson Luiz Ferrandini ${ }^{\mathrm{a}}$, Denis Jardim Villarinho ${ }^{\mathrm{a}}$,

\author{
Gerhard Hans Knörnschild ${ }^{\mathrm{b} *}$, Lírio Schaeffer \\ ${ }^{a}$ Laboratório de Transformação Mecânica - LdTM, Centro de Tecnologia, \\ Universidade de Federal do Rio Grande do Sul-UFRGS, Av. Bento Gonçalves, $n^{\circ}$. 9500, \\ CEP 91501-970, Porto Alegre, RS, Brazil \\ ${ }^{\mathrm{b}}$ Laboratório de Processos Eletroquímicos e Corrosão - Eletrocorr, \\ Universidade de Federal do Rio Grande do Sul - UFRGS, \\ Av. Bento Gonçalves, $n^{\circ}$. 9500, CEP 91501-970, Porto Alegre, RS, Brazil
}

Received: March 18, 2011; Revised: May 9, 2011

\begin{abstract}
The present work reports a comparative study of cemented carbides of compositions WC-6Co, WC-10Co, WC-20Co, WC-6Co-6Ni and WC-12Ni-6Co. The purpose was to study the powder metallurgical production process of these compositions starting from a commercial WC-6Co powder, obtaining the desired compositions by mass balance with pure Co and pure Ni powders. During the process steps mixing, milling, compacting and sintering the powders were described by its apparent density, green density, shrinkage and sintered density. Lower densities were observed in composites with higher binder content. The process was monitored by scanning electron microscopy and EDS analysis to evaluate the homogeneity of the powders, to detect contaminations by the process and to characterize the microstructure of the sintered materials. A finer microstructure was found when the binder contained Ni. Potentiodynamic polarization tests in sulfuric acid revealed pseudo-passive behavior for all the tested hard metals.
\end{abstract}

Keywords: powder metallurgy, hard metal, WC-Co, WC-Co-Ni

\section{Introduction}

Hard metals are essentially composed of WC particles incorporated in a Co matrix. Their characteristics are high hardness and wear resistance, resistance to compression, tenacity and thermal stability. The properties are defined by the combination of the properties of the carbides and of the matrix. Other carbide forming elements, present in many hard metals, are $\mathrm{Ti}, \mathrm{Ta}, \mathrm{V}, \mathrm{Nb}$. The addition of small quantities of these elements has the function to inhibit WC grain growth during sintering ${ }^{1-5}$. WC dissolves in the Co matrix during sintering and precipitates again at other carbide particles during cooling. In this way particle coarsening occurs since small carbides dissolve preferentially and reprecipitate at greater particles. Together with the grain growth the morphology of the carbides changes ${ }^{1}$. The carbon content is another important aspect which modifies the properties of hard metals. The carbon content has to be between 6.15 and $6.20 \mathrm{wt}$. (\%), in the matrix phase between 0.10 and 0.18 wt. (\%). Higher carbon contents cause reprecipitation of carbon as free graphite ${ }^{6,7}$.

The role of Co in hard metals is to form a ductile matrix for the carbide particles. During liquid phase sintering it permits to obtain material of high density ${ }^{8}$. Commercial hard metals have a Co content between 3 and 25 wt. $(\%)^{9}$.

Due to the excellent wettability of WC by the liquid phase considerable contraction is observed during sintering at about $1300{ }^{\circ} \mathrm{C}$. Solidification of Co occurs at about $1275{ }^{\circ} \mathrm{C}$; during subsequent cooling about $4 \mathrm{wt}$. $(\%)$ of $\mathrm{WC}$ is retained in solution. At room temperature the dissolved WC in the Co binder is less than 1 wt. $(\%)^{10,11}$.
Nickel, a ductile metal, is sometimes added to modify the binder composition. The most important aim of this modification with $\mathrm{Ni}$ is to improve the corrosion resistance of the hard metal ${ }^{12}$.

In the present work the powder metallurgical production of WCCoNi composites is documented, using as raw material a commercial WC-6Co powder. The influence of $\mathrm{Ni}$ on the different production steps is monitored by electron microscopy and EDS. The influence of Ni on the electrochemical behavior is examined by voltammetric curves.

\section{Materials and Methods}

Commercial WC-6\% Co powder with purity of $99 \%$ and granulometry of -325 Mesh was delivered by Alfa Aesar. Powders of the pure metals, Co and $\mathrm{Ni}$, (99\% purity, $-400 \mathrm{Mesh}$ ) were also delivered by Alfa Aesar.

Composites with the desired composition were obtained by mixing the commercial WC-6Co powder with the pure metal powders.

Using mass balance calculations the necessary quantities of $\mathrm{Co}$ and $\mathrm{Ni}$ were determined, which have to be added to $100 \mathrm{~g}$ of WC-6Co in order to obtain the following materials: $90 \mathrm{WC}-10 \mathrm{Co}$, 80WC-20Co, 94WC-6Co, 88WC-6Co-6Ni, 82WC-6Co-12Ni. The calculated quantities of $\mathrm{Co}$ and $\mathrm{Ni}$ are listed in Table 1.

The powder mixture was prepared in two steps: At first the powder components were put in an attritor mill and mixed one hour at $100 \mathrm{rpm}$ in ethylic alcohol under argon atmosphere. In the second step the powder mixture was homogenized during 30 minutes in a Y-mixer with the addition of 1.5 wt. (\%) zinc stearate as lubricant. 
After mixing the powders were pressed in a cylindrical matrix with a compacting pressure of $200 \mathrm{MPa}$.

Sintering was performed under argon atmosphere in a tubular furnace with electronic control and precision of $+/-1{ }^{\circ} \mathrm{C}$. A sintering cycle consisted of heating up to $580{ }^{\circ} \mathrm{C}$ at $5.8^{\circ} \mathrm{C} / \mathrm{min}$, holding the temperature at $580{ }^{\circ} \mathrm{C}$ for 20 minutes. In the following heating continued with $8{ }^{\circ} \mathrm{C} / \mathrm{min}$ up to the sintering temperature, which was held for 60 minutes. Afterwards the furnace was cooled down at a rate of $6{ }^{\circ} \mathrm{C} / \mathrm{min}$.

The following sintering temperatures were applied: WC-6Co at $1450{ }^{\circ} \mathrm{C}$; WC-10Co at $1420{ }^{\circ} \mathrm{C}$; WC-6Co-6Ni at $1400{ }^{\circ} \mathrm{C}$; WC-6Co-12Ni and WC-20Co at $1360{ }^{\circ} \mathrm{C}$.

The different steps of powder processing were monitored by scanning electron microscopy and EDS-analysis, in order to evaluate homogeneity of the mixture and to identify possible powder contamination. Voltammetric experiments were fulfilled using a potentiostat with computer based data acquisition and control and a conventional three-electrode-cell. The counter electrode was made of platinum wire. The reference electrode was $\mathrm{AgCl} / \mathrm{Ag}$ and connected to the cell by a salt bridge and a Haber-Luggin capillary.

The samples were cleaned with ethylic alcohol in an ultrasonic bath and mounted in a PTFE holder, which exposed the front side of the cylindrical samples and permitted electrical contact at the back side. Tests were performed in $1 \mathrm{~N} \mathrm{H}_{2} \mathrm{SO}_{4}$ solution at room temperature. The solution was open to air. The scan rate was $10 \mathrm{mV} / \mathrm{min}$. The start potential was $-0.5 \mathrm{~V}(\mathrm{SHE})$.

Table 1. Mass of Co and Ni added to $100 \mathrm{~g}$ of commercial WC-6Co composite to obtain hard metals of defined compositions.

\begin{tabular}{lcccc}
\hline Hard metal & $\begin{array}{c}\text { Addition } \\
\text { of Ni (g) }\end{array}$ & $\begin{array}{c}\text { Addition } \\
\text { of Co }(\mathrm{g})\end{array}$ & $\begin{array}{c}\text { Total mass } \\
\text { of Co }(\mathrm{g})\end{array}$ & $\begin{array}{c}\text { Total mass } \\
\text { of Ni (g) }\end{array}$ \\
\hline WC-6Co & 0 & 0 & 6 & 0 \\
WC-10Co & 0 & 4.5 & 10.5 & 0 \\
WC-6Co-6Ni & 6.4 & 0.4 & 6.4 & 6.4 \\
WC-6Co-12Ni & 14 & 1 & 7 & 14 \\
WC-20Co & 0 & 17.5 & 23.5 & 0 \\
\hline
\end{tabular}

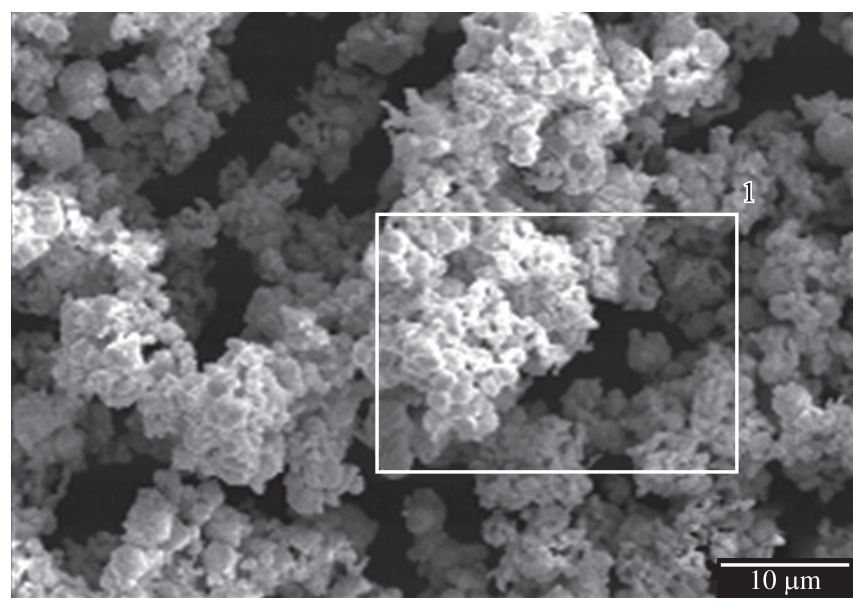

Full scale counts: 2254

Base (45)_pt1

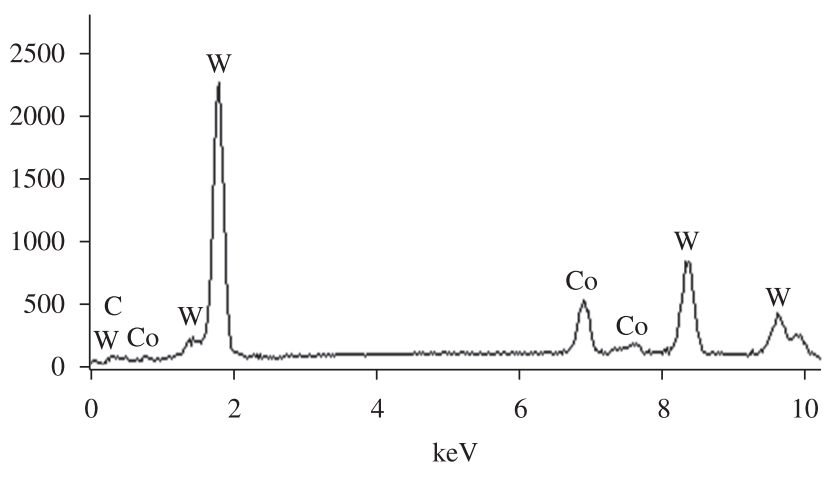

(b)

Figure 1. a) Micrograph of WC-6Co-powder. b) EDS of selected area in Figure 1a. 


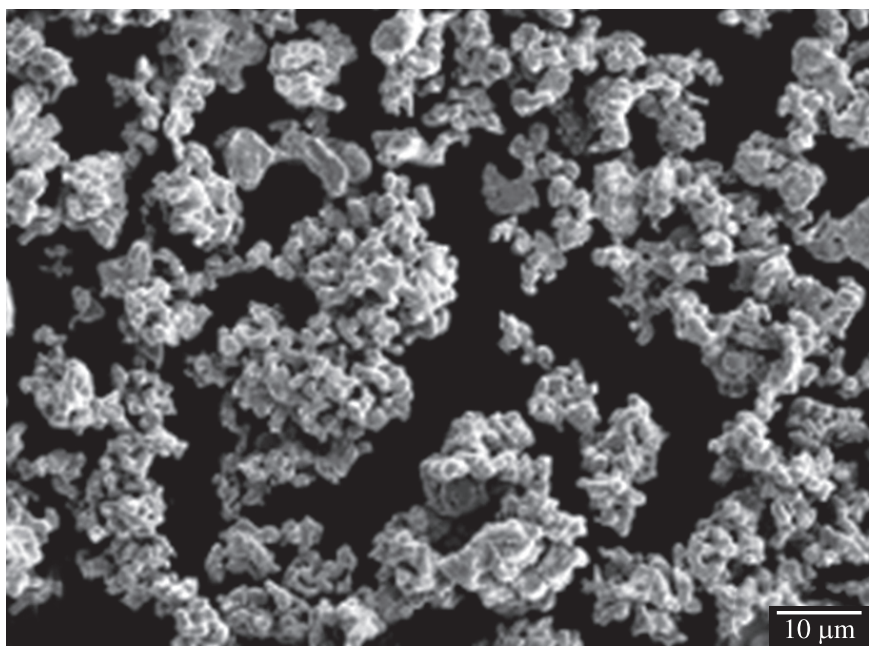

(a)

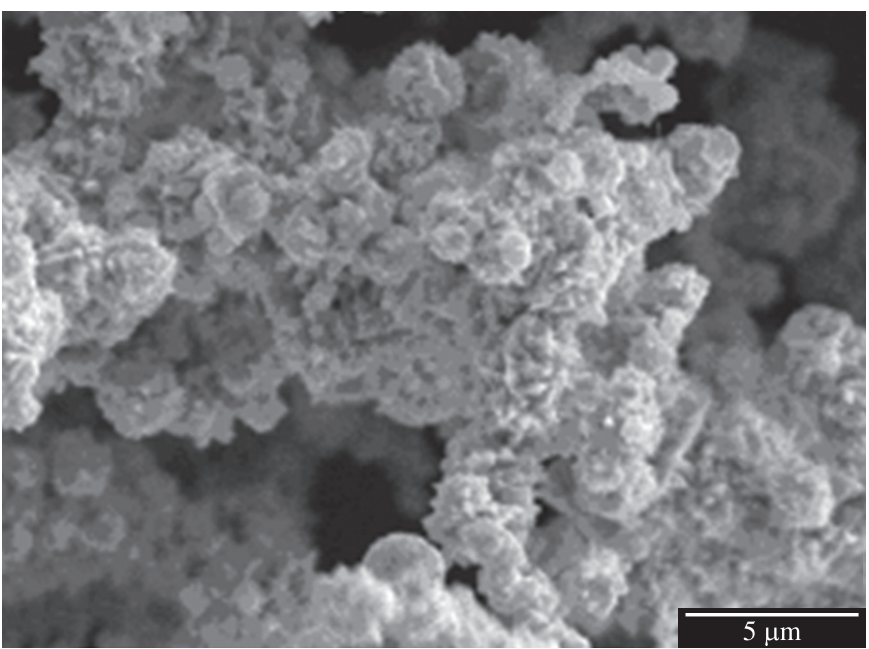

(b)

Figure 2. a) Micrograph of pure Co-powder. b) Micrograph of pure Ni-powder.

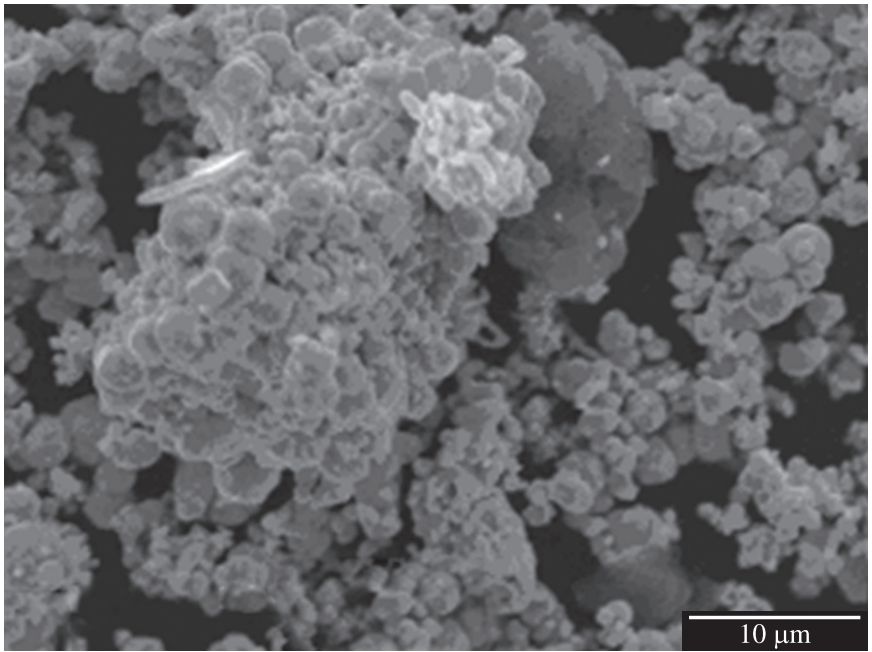

(a)

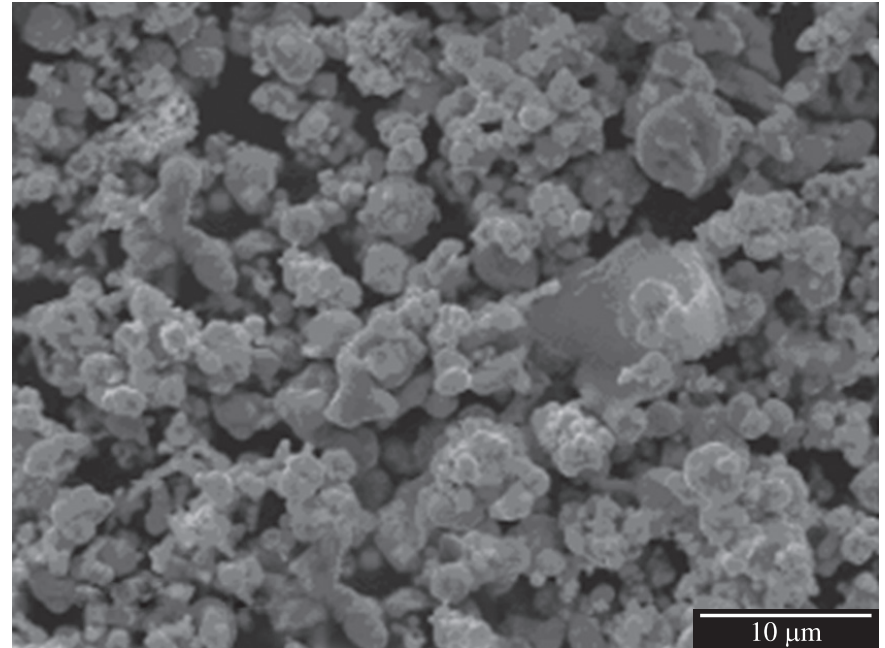

(b)

Figure 3. a) Micrograph of WC-10Co. b) Micrograph of WC-20Co.

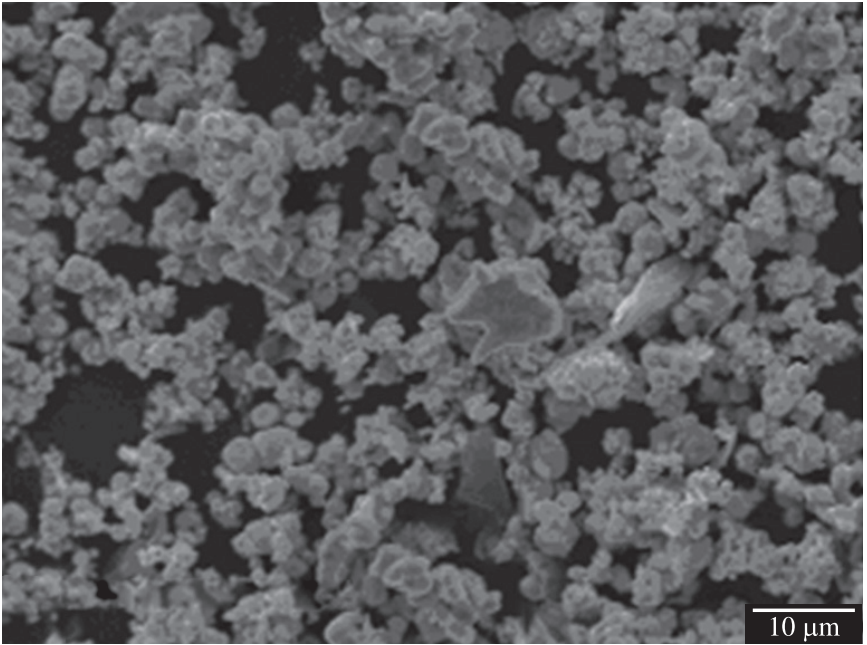

(a)

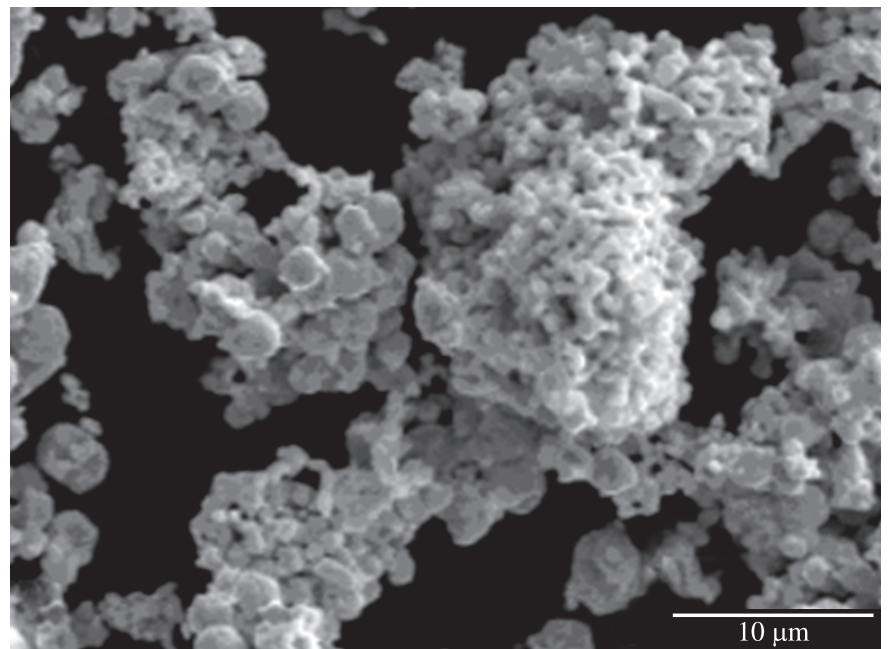

(b)

Figure 4. a) Micrograph of WC-6Co-6Ni. b) Micrograph of WC-6Co-12Ni. 


\subsection{Sintered hard metals}

After the sintering treatment described above, the density of the sintered hard metals was determined by Arquimedes' principle, in accordance with the MPIF-95 norm (Table 4). With increasing binder phase contents lower relative densities were determined. Also, the comparison of WC-6Co-12Ni and WC-20Co indicates that $\mathrm{Ni}$ in the binder phase lowers the relative density.

Volumetric and linear contractions of the hard metal are compared in Table 5. Radial contraction was smaller than axial contraction, since the latter is more strongly influenced by variations of compacting pressure, temperature and duration of sintering.

Sintered alloys were studied by scanning electron microscopy, which revealed the microstructure better than light microscopy with Murakami attack. Electron microscopic studies showed that sintering of the WC-6Co and WC-10Co powders (Figure 5) led to a homogeneous distribution of the carbide particles and the Co binder

Table 2. Apparent density of the hard metals.

\begin{tabular}{cc}
\hline Composition of hard metal & Apparent density $\left(\mathrm{g} \cdot \mathrm{cm}^{-3}\right)$ \\
\hline WC-6\%Co & $2.63 \pm 0.02$ \\
WC-10\%Co & $2.57 \pm 0.04$ \\
WC-6\%Co6Ni & $2.55 \pm 0.03$ \\
WC-6\%Co12Ni & $2.47 \pm 0.03$ \\
WC-20\%Co & $2.45 \pm 0.02$ \\
\hline
\end{tabular}

Table 3. Green density of the compacted hard metals.

\begin{tabular}{cc}
\hline Composition & Green density $\left(\mathrm{g} \cdot \mathrm{cm}^{-3}\right)$ \\
\hline WC-6Co & $8.02 \pm 0.13$ \\
WC-10Co & $7.80 \pm 0.16$ \\
WC-6Co-6Ni & $7.62 \pm 0.19$ \\
WC-6Co-12Ni & $7.11 \pm 0.18$ \\
WC-20\%Co & $7.03 \pm 0.12$ \\
\hline
\end{tabular}

Table 4. Density of sintered hard metals

\begin{tabular}{cccc}
\hline $\begin{array}{c}\text { Composition of } \\
\text { hard metals }\end{array}$ & $\begin{array}{c}\text { Density of } \\
\text { sintered materials } \\
\left(\mathrm{g} . \mathrm{cm}^{-3}\right)\end{array}$ & $\begin{array}{c}\text { Theoretic } \\
\text { density } \\
\left(\mathrm{g} . \mathrm{cm}^{-3}\right)\end{array}$ & $\begin{array}{c}\text { Relative } \\
\text { density }(\%)\end{array}$ \\
\hline WC-6Co & $14.64 \pm 0.06$ & 14.90 & $97.8-98.6$ \\
WC-10Co & $14.19 \pm 0.16$ & 14.60 & $96.1-98.3$ \\
WC-6Co-6Ni & $13.40 \pm 0.21$ & 14.30 & $92.3-95.2$ \\
WC-6Co-12Ni & $13.05 \pm 0.21$ & 13.76 & $93.3-96.4$ \\
WC-20Co & $13.13 \pm 0.14$ & 13.60 & $95.5-97.6$ \\
\hline
\end{tabular}

Table 5. Volumetric and linear contraction of the hard metals.

\begin{tabular}{cccc}
\hline $\begin{array}{c}\text { Composition of } \\
\text { hard metal }\end{array}$ & $\begin{array}{c}\text { Volumetric } \\
\text { contraction } \\
(\%)\end{array}$ & $\begin{array}{c}\text { Linear } \\
\text { contraction } \\
\text { (height) }(\%)\end{array}$ & $\begin{array}{c}\text { Linear } \\
\text { contraction } \\
\text { (diameter) }(\%)\end{array}$ \\
\hline WC-6Co & $43.6-48.6$ & $17.2-19.3$ & $19.0-19.8$ \\
WC-10Co & $43.8-47.8$ & $17.1-19.3$ & $19.0-19.8$ \\
WC-6Co-6Ni & $43.6-48.7$ & $17.3-19.5$ & $19.0-19.7$ \\
WC-6Co-12Ni & $44.1-48.7$ & $17.3-19.5$ & $18.9-19.8$ \\
WC-20Co & $43.8-48.5$ & $17.3-19.4$ & $19.0-19.8$ \\
\hline
\end{tabular}

phase. Diffusion between carbides and grain growth was observed. Small islands of Co are present in the WC-10Co material. EDS analysis showed only the presence of elements from the raw materials. No sign of contamination by the production process was detected (Figure 6). This applies to all compositions studied.

The microstructure of the Ni-containing samples differs from the Ni-free ones (Figure 7). A finer and more homogeneous distribution

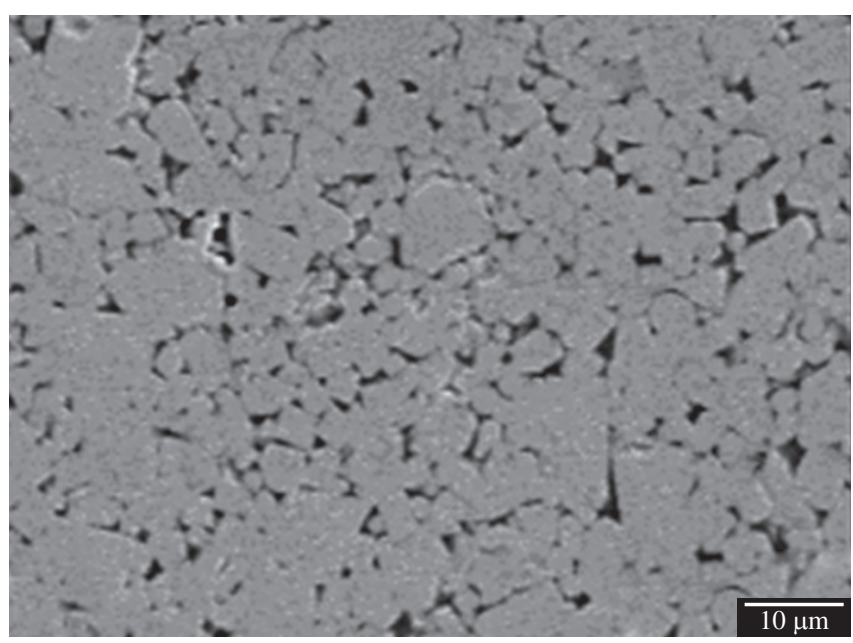

(a)

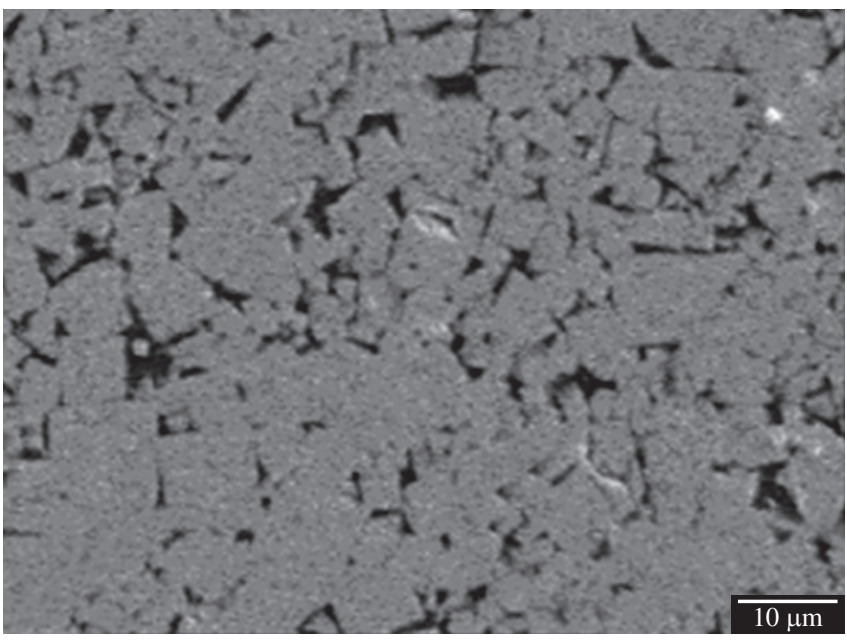

(b)

Figure 5. a) WC-6Co, sintered at $1450^{\circ} \mathrm{C}$. b) WC-10Co sintered at $1420^{\circ} \mathrm{C}$.

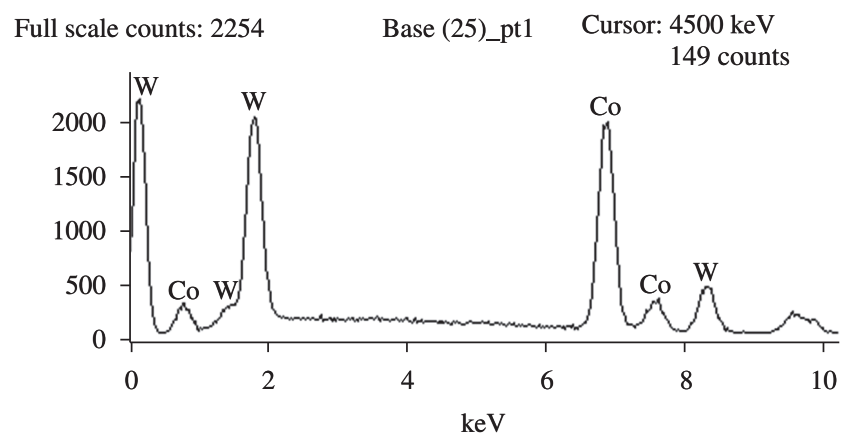

Figure 6. EDS analysis of WC-10Co sintered at $1420^{\circ} \mathrm{C}$. 


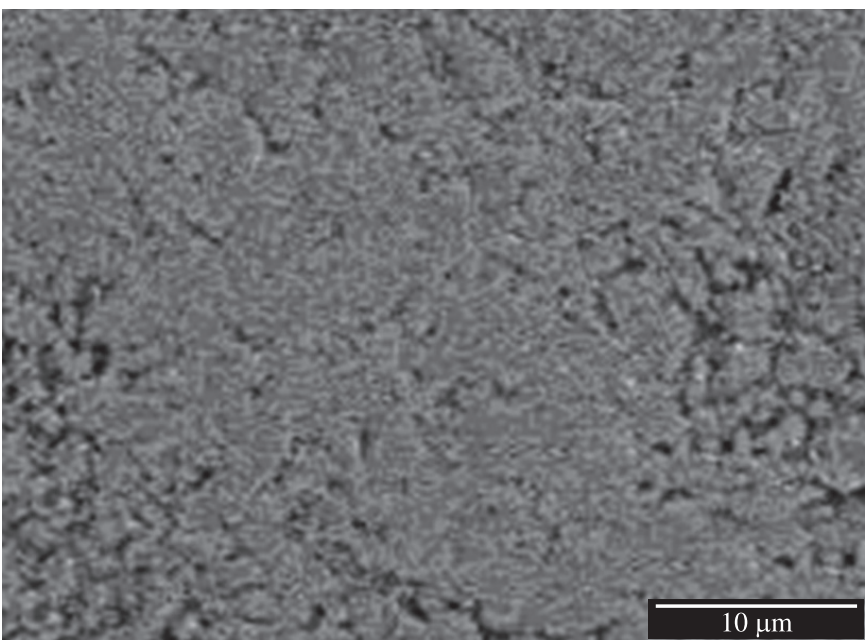

(a)

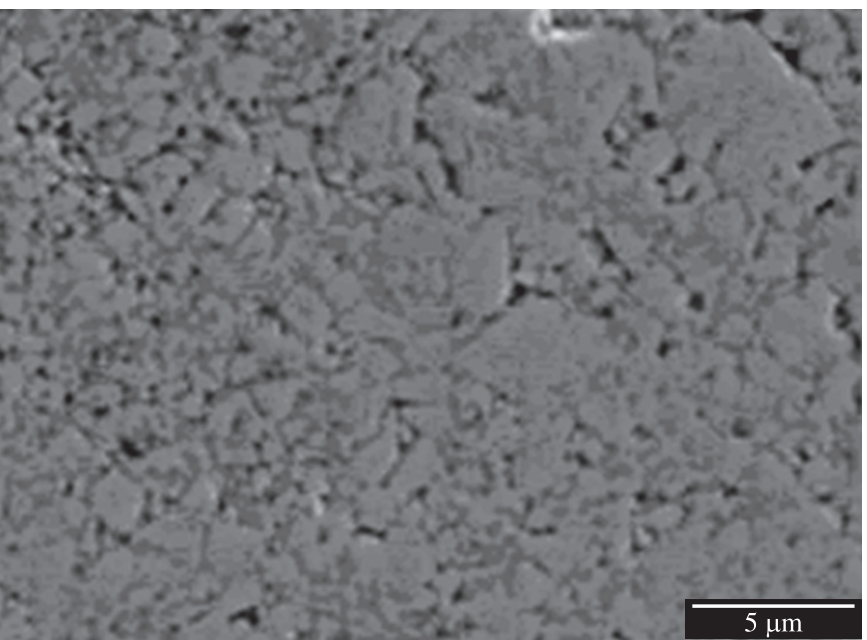

(b)

Figure 7. a) WC-6Co-6Ni sintered at $1400{ }^{\circ} \mathrm{C}$. b) $\mathrm{WC}-6 \mathrm{Co}-12 \mathrm{Ni}$ sintered at $1360{ }^{\circ} \mathrm{C}$.

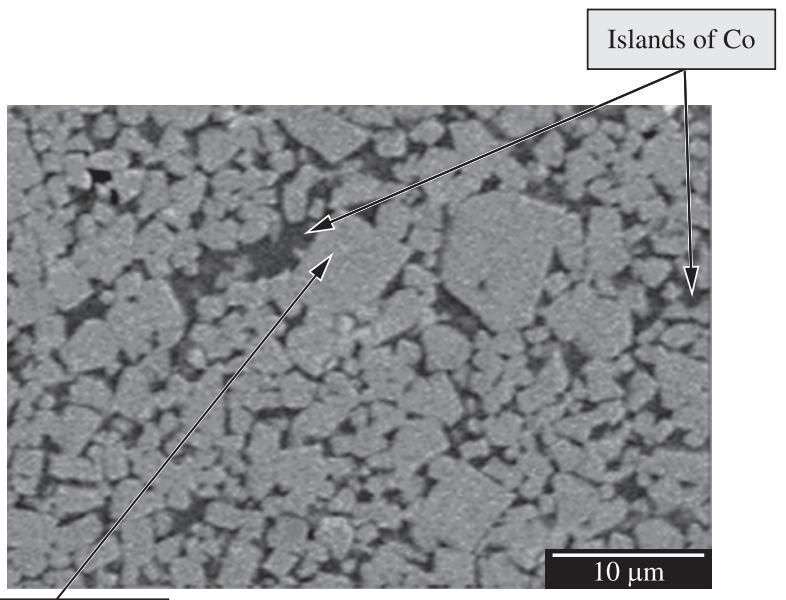

Growth of carbide particles

Figure 8. Sem of WC-20Co sintered at $1360{ }^{\circ} \mathrm{C}$.

of carbides and of $\mathrm{Ni}$ and $\mathrm{Co}$ binder was found, especially in the WC-6Co-6Ni material (Figure 7a). No distinction between Co and $\mathrm{Ni}$ binder could be made, nor could be detected islands of $\mathrm{Co}$ or $\mathrm{Ni}$, despite of a total binder content of $12 \%$. Small islands of binder phase were found in WC-6Co-12Ni. Growth of carbide particle up to more than $10 \mu \mathrm{m}$ can be observed in some parts of the specimen (Figure 7b).

The sintered WC-20Co shows islands of Co and growth of carbide particles, some of them reaching about $10 \mu \mathrm{m}$ (Figure 8). Due to the higher binder content WC particles are completely surrounded by Co.

\subsection{Electrochemical behavior}

Potentiodynamic tests in $\mathrm{H}_{2} \mathrm{SO}_{4}$ were performed in order to get an overview of the electrochemical behavior of the sintered hard metals. Figure 9 compares the curves as a function of the Co-binder content. The cathodic curves are nearly identical for the three compositions studied. The same observation was made with respect to the anodic Tafel lines. Therefore the corrosion potentials of the three hard metals are similar. At higher anodic potentials WC20Co reaches a

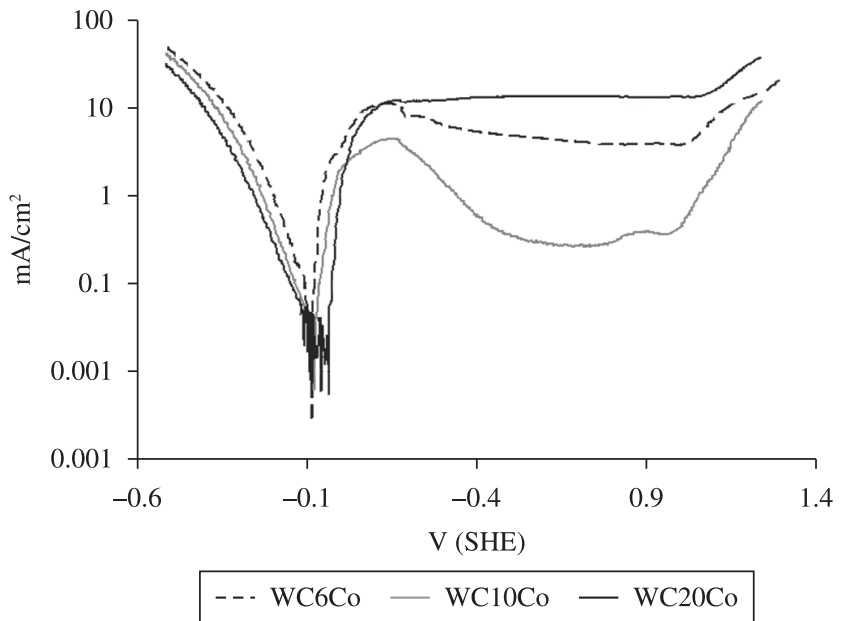

Figure 9. Potentiodynamic curves of hard metals as a function of Co-binder content.

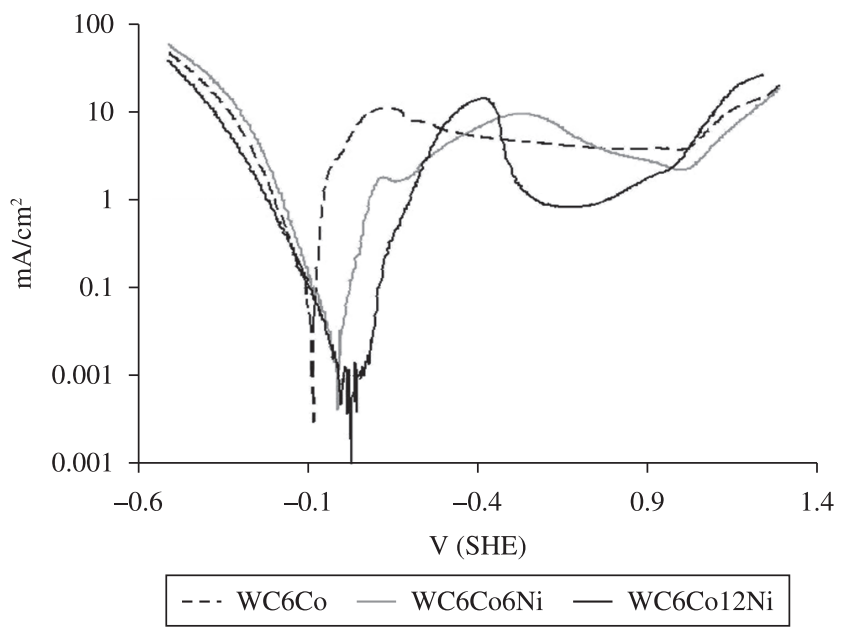

Figure 10. Potentiodynamic curves of hard metals as a function of $\mathrm{Ni}$-content in the binder. 
current density plateau of about $10 \mathrm{~mA} \cdot \mathrm{cm}^{-2}$. With lower Co content the current density in the anodic potential region becomes smaller. However, WC10Co showed a lower current density than WC6Co, which indicates that other parameter than the binder content might have an influence. This question is also controversially discussed in the literature. Some works report lower current densities with lower binder content ${ }^{13}$, while others found that the binder content has no influence ${ }^{14}$. Also, others report that the current density depends on the carbide grain size ${ }^{15}$.

Figure 10 compares hard metals with different Ni contents. The cathodic curves show a small influence of the $\mathrm{Ni}$ content. The anodic curves, however, are shifted to higher potentials with growing $\mathrm{Ni}$ content. Therefore, the corrosion potential is also shifted to higher potentials and the corrosion current density becomes smaller with growing Ni content. At higher anodic potentials current densities remain high in all examined materials. Transpassive behavior begins above approximately $+1 \mathrm{~V}$.

\section{Conclusions}

The powder metallurgical production route of $\mathrm{WC}-\mathrm{Co}$ and WC-CoNi hard metals, starting from a commercial WC-6Co powder, gave satisfactory results for the analysed compositions: WC-10Co, WC-20Co, WC-6Co-6Ni and WC-6Co-12Ni. A homogeneous distribution of the added $\mathrm{Co}$ and $\mathrm{Ni}$ powders was found, showing that the mixing, milling, compacting and sintering procedures were performed with adequate parameters. No contamination with elements other than the constituents of the raw materials was detected by EDS analysis.

A comparison of sintered density and sintering temperature of the examined alloys shows that sintering temperature is the main factor which determinines the density. The highest sintered density was obtained with the commercial WC-6Co powder which was sintered at the highest temperature. In the case of WC-6Co the different production process of the commercial material might also have an influence on the results. The comparison of WC-6Co- $12 \mathrm{Ni}$ and $\mathrm{WC}-20 \mathrm{Co}$ indicates that $\mathrm{Ni}$ in the binder phase tends to lower the relative density.

Carbide grain growth was observed in all sintered materials, however, a finer distribution of the constituents, WC particles and $\mathrm{Co}-\mathrm{Ni}$ binder phase, was found in the composition WC-6Co-6Ni.

In the potentiodynamic corrosion tests in sulfuric acid all materials showed a behavior described sometimes as "pseudopassive" 16 , which means that the current density in the passive range remains high due to non-adherent, non-protecting corrosion products. The Ni-containing hard metals showed a shift of the anodic curve of metal dissolution, indicating a decrease of the corrosion current density with growing $\mathrm{Ni}$ content in the binder.

\section{Acknowledgements}

The authors gratefully acknowledge financial support by FINEP and by IMER Usinagem Porto Alegre - RS.

\section{References}

1. Silva AGP. The Role of Bender Phase in The WC-Co Sintering. Materials Research. 2001; 4(2):59-62. http://dx.doi.org/10.1590/S151614392001000200003

2. Rodrigues MF, Bobrovnitchii GS, Quintanilha R, Cândido R, Silva G and Filgueira M. Sinterização da Liga WC/10Co Por Altas Pressões. Revista Matéria. 2006; 11(3):174-180.

3. Thümmler $\mathrm{F}$ and Oberacker R. An introduction to powder metallurgy. Cambridge, Great Britain: The Institute of Materials; 1993. p. 280-285

4. Schäfer F, Kolaska H and Grewe H. Hartmetallwerkzeuge im Bergbau: Pulvermetallurgie der Hartmetalle. Deutschland: FPM-Fachverband Pulvermetallurgie, 1992. Kapitel 15.

5. Gomes UU, Buriti AC and Silva AGP. Computer Modelling of WC Crystallite Cross Section Distribution in WC-Co Hardmetal Grade. In: Powder Metallurgy World Congress; 1998; Granada, Espanha. Granada: European Powder Metallurgy Association; 1998.

6. Phase diagram. Available from: <http://www.infomet.com.br/diagramasfases-ver.php? $=$ mostrar\&jd_diagrama $=120 \& b t n \_f i l t r a r=o k>$. Access in: 25/12/2010.

7. Machado FAL, Filgueira M, Esquef I, Vargas $H$ and Faria Junior RT. Caracterização térmica, estrutural e mecânica da liga de Metal duro WC-10 \% Co. In: Anais do $17^{\circ}$ Congresso Brasileiro de Engenharia e Ciência dos Materiais - CBECIMat; 2006, Foz do Iguaçu, Brasil. Foz do Iguaçu: IPEN; 2006.

8. Available from: <http://www.webelements.com/cobalt/>. Access in: 24/11/2009.

9. Crook P. Corrosion of Cobalt-Base Alloys. In: ASM Metals HandBook: Properties and Selection Nonferrous Alloys and Special Purpose Materials. 9th ed. Washington: ASTM; 1998. vol. 2, p. 1404-1406.

10. Cemented Carbides. Powder Metallurgy Cermets and Cemented Carbides. In: ASM Metals HandBook: Powder Metal Technologies and Applications. 9th ed. Washington: ASM International; 1998. vol. 7, p. 2337.

11. Chiaverini V. Metalurgia do pó. 4th ed. São Paulo, Brasil: Associação Brasileira de Metalurgia e Materiais-ABM; 2001. p. 184-187.

12. Paganini PP. Síntese e caracterização de trocadores iônicos inorgânicos a base de óxidos mistos estanho-titânio para utilização na recuperação de cádmio e níquel e estudos fotoluminescentes. [Dissertação]. São Paulo: Instituto de Pesos e Medidas; 2007.

13. Human AM and Exner HE. Electrochemical Behavior of TungstenCarbide Hard Metals. Materials Science and Engineering: A. 1996; 209:180-191. http://dx.doi.org/10.1016/0921-5093(95)10137-3

14. Human AM and Exner HE. The relationship between electrochemical behaviour and in-service corrosion of WC based cemented carbides. International Journal of Refractory Metals and Hard Materials. 1997; 15:65-71. http://dx.doi.org/10.1016/S0263-4368(96)00014-5

15. Tomlinson WJ G and Ayerst J. Anodic polarization and corrosion of WC-Co hardmetals. Journal Materials Science. 1989; 24:2348-2354. http://dx.doi.org/10.1007/BF01174495

16. Sutthiruangwong S, Mori G and Kösters R. Passivity and pseudopassivity of cemented carbides. International Journal of Refractory Metals and Hard. 2005; 23:129-136. http://dx.doi.org/10.1016/j.ijrmhm.2004.11.006 